\title{
Production of Adenoviral Vectors in 293 Cells: A Case Study of the Adaptation of Attached Cells to Grow in Suspension
}

\author{
Alejandro Negrete ${ }^{1,2, *}$, Tau Chuan Ling ${ }^{1,3}$ and Andrew Lyddiatt ${ }^{1,4}$
}

\begin{abstract}
${ }^{I}$ Biochemical Recovery Group, Department of Chemical Engineering, School of Engineering, University of Birmingham, Edgbaston, Birmingham B15 2TT, UK; ${ }^{2}$ Current address: US National Institutes of Health, National Heart, Lung, and Blood Institute, Bethesda, MD 20892, USA ${ }^{3}$ Current address: Department of Process and Food Engineering, Faculty of Engineering, University Putra Malaysia, 43400 UPM Serdang, Selangor, Malaysia and ${ }^{4}$ Current address: Millipore Biopharmaceutical Division, Bioprocessing Ltd, Medomsley Road, Consett DH8 6SZ, UK
\end{abstract}

\begin{abstract}
A study of the production of adenoviral vectors in suspension 293 cells has been explored. A defined serumfree medium (293 SFM II) formulated without human or animal origin components from Invitrogen was used for the suspension adapted 293 cells. It was demonstrated that the 293 cells can be adapted to grow in suspension using serum free medium. The effect of different cell culture parameters was determined. The production technique demonstrated here is expected to simplify purification processes and circumvents the problems associated with serum containing medium.
\end{abstract}

Key Words: Adenoviral vectors, serum-free medium, 293 cells, cell culture, suspension.

\section{INTRODUCTION}

Adenoviral vectors have been extensively used for recombinant DNA vaccines and gene therapy $[1,2]$. The methods to produce adenoviral vectors for Phase I clinical trials have mainly been dependent upon attached 293 cells grown as a monolayer [3]. Apart from being labor intensive this method has limited potential for scale-up $[4,5]$. Additionally, the geometric configuration of such a method limits the maximal production of viruses from a technical and economical point of view $[6,7]$. Likewise, cell culture using commercially available microcarriers has some drawbacks such as limitations in scaling-up, high cost implications, cell damage caused by the collisions between microcarriers and the internals of a stirred bioreactor. In addition, the adenoviral vector yield is not as high as that reported for cells in suspension $[3,8,9]$.

The production of adenoviral vectors in a suspension culture has obvious advantages over monolayer cultures in terms of efficiency, economy and potential for automation. Even though the 293 cells tend to grow in attached form, the line can be adapted to grow in suspension using serumcontaining medium (SCM) [7]. Although 293 cells tend to aggregate in suspension culture reducing the cell viability and virus production [10], previous reports have shown that $1 \mathrm{~L}$ of infected 293 cells can produce as much virus as approximately 30 to $40150 \mathrm{~mm}$ dishes with infected attached 293 cells [7].

Complex SCM has been used to grow 293 cells in attached and suspension culture $[7,11]$ and recombinant proteins have been successfully expressed via adenovirus in such cultures $[12,13]$. The production of adenoviral vectors for gene therapy applications has also been reported using

*Address correspondence to this author at the National Institutes of Health, National Heart, Lung, and Blood Institute, 9000 Rockville Pike Bldg 10, Rm 7D04, Bethesda, MD 20892, USA; Tel: +1-301-496-6104; Fax: +1-301496-9985; E-mail: negretea@nhlbi.nih.gov attached or clumped 293 cells in serum contained medium (SCM) $[12,14]$ and serum-free medium (SFM) in 293 cells grown in suspension $[15,16]$. According to the information available in current literature the production of adenoviral vectors in 293 cells grown in suspension in SCM in a $20 \mathrm{~L}$ bioreactor [17] and in a customized SFM in a $10 \mathrm{~L}$ bioreactor [18] has been reported. However, with the customized SFM a maximum yield of $10^{3}$ infective particles was obtained at 48 hours post infection (hpi). There are numerous problems associated with the presence of serum in culture media such as the possible addition of adventitious agents. This, in conjunction with the serum proteins, complicates the downstream processing and risks batch-to-batch variability, which implicates regulatory considerations. In addition, there is a high cost involved, which represents around $40 \%$ of the total cost of the medium [19]. The price comparison was obtained from current prices of a liter of medium for attached and suspension HEK 293 cells (Invitrogen Corp., Carlsbad, CA and Sigma-Aldrich Ltd, UK). These concerns are increased when the final product is to be used as an injectable therapeutic [9].

The objective of the work in this paper was to study the production of adenoviral vectors in suspension adapted 293 cells compared to attached cells. Different parameters including aeration, agitation, and cell viability were studied. A defined SFM (293 SFM II) formulated without human or animal origin components from invitrogen was used for the suspension adaptation and high density culture of 293 cells. This medium has low protein content $(10 \mathrm{mg} / \mathrm{L})$, which potentially simplifies purification processes and circumvents the problems mentioned previously.

\section{MATERIALS AND METHODOLOGY}

\section{Cell Lines}

In this study three cell lines were used including the A549 lung epithelial carcinoma cell line, the human embry- 
onic retinal 911 cell line and the 293 cell line. The A549 is a non-complementing cell line and was kindly donated by $\mathrm{Dr}$ Peter Searle, Institute of Cancer Studies, University of Birmingham, UK. This cell line was utilized for flow cytometric analysis. The 293 and the 911 cell lines were obtained from Invitrogen. Both 293 and 911 cell lines are E1-complementing supporting the replication of E1-deleted replicationdefective adenoviruses. For the production of adenoviral vectors in T-flasks, the 293 cells were grown in attached form in SCM and in suspension in SFM. The 911 cell line was used for infectivity determination by plaque assay [20].

\section{Conservation}

The three attached cell lines were cultured in Dulbecco's Modified Eagle's Medium (DMEM) obtained from SigmaAldrich Ltd, UK, and supplemented with $10 \%$ heat-inactivated $\left(56^{\circ} \mathrm{C}, 30 \mathrm{~min}\right)$ fetal calf serum (hiFCS; Mycoplex, PAA Laboratories). Cell lines were subcultured every 3 to 4 days following digestion at room temperature with $0.5 \mathrm{ml}$ trypsin/EDTA (Sigma-Aldrich Ltd, UK). The 293 cells were adapted to grow in suspension in serum free medium 293 SFM II (Invitrogen). The suspension adapted 293 cells were subcultured every $48 \mathrm{~h}$ by centrifugation and resuspension in fresh medium to maintain the cell density at $2 \times 10^{5}$ cells $/ \mathrm{ml}$. All cultures were maintained at $37^{\circ} \mathrm{C}$ in an incubator with a $5 \% \mathrm{CO}_{2}$ atmosphere. Cell densities were determined using the standard trypan blue exclusion method and a hemocytometer and reported as cells $/ \mathrm{cm}^{2}$ or cells $/ \mathrm{ml}$ for attached and suspended cells, respectively (Sigma-Aldrich catalogue). The viability reported as a percentage was determined by comparing the total number of cells to the number of viable cells.

\section{Cell Growth and Infection in Flasks}

The attached 293 and A549 cells were grown in standard tissue culture plasticware (T-25 flasks) using DMEM supplemented with $10 \%$ hiFCS. Once confluence was reached $(48 \mathrm{~h})$ one flask was used for cell counting in order to calculate the number of adenoviral vectors necessary for infection. This number was given as the multiplicity of infection (MOI) and represented the number of infective adenoviral vectors available per cell in culture. The medium in the remaining flasks was replaced with fresh medium containing the adenoviral vectors at a specific value of MOI. Cultures were incubated at $37^{\circ} \mathrm{C}$ in $5 \% \mathrm{CO}_{2}$ for $90 \mathrm{~min}$ with gentle shaking every $20 \mathrm{~min}$. After infection, $30 \mathrm{ml}$ of fresh DMEM was added. During five consecutive days, the cells of one flask were harvested. The 293 cells growing in suspension, were concentrated by centrifugation at cell densities of $2 \times 10^{5}$ cells $/ \mathrm{ml}$ and infected at the required value of MOI for $90 \mathrm{~min}$ with gentle shaking every $20 \mathrm{~min}$. The $293 \mathrm{SFM}$ II was added to complete the total volume $(10 \mathrm{ml})$. Cultures were incubated at $37^{\circ} \mathrm{C}$ in a $5 \% \mathrm{CO}_{2}$ atmosphere.

\section{Cell Growth and Infection in Spinner Flasks}

The suspension adapted 293 cells were grown in $250 \mathrm{ml}$ spinner flasks in 293 SFM II. Cultures were incubated at $37^{\circ} \mathrm{C}$ in a $5 \% \mathrm{CO}_{2}$ atmosphere and agitated with a magnetic stirrer at $100 \mathrm{rpm}$. Cells were infected in the same way as the suspension cells grown in flasks. After the infection, $120 \mathrm{ml}$ of fresh medium was added. Cells were incubated for additional 48 h.

\section{Crude Virus Lysate Preparation}

Cells were harvested at 48 hpi unless otherwise stated. For attached cells, $0.5 \mathrm{ml}$ trypsin/EDTA at room temperature (approximately $20^{\circ} \mathrm{C}$ ) was used while suspension adapted 293 cells were harvested by centrifugation at $2000 \mathrm{~g}$ for 10 min at $4{ }^{\circ} \mathrm{C}$. The cell pellets were resuspended in sterile Dulbecco's Phosphate Buffered Saline (PBS; Invitrogen) supplemented with $10 \%(\mathrm{v} / \mathrm{v})$ glycerol at a cell density of $1 \times 10^{7}$ cells/ml.

The cells were lysed with three cycles constituting snap freeze in liquid nitrogen following thawing in a $37^{\circ} \mathrm{C}$ water bath. This procedure was carried out placing the universal containing the harvested cells suspended in buffer using a proper container with liquid nitrogen. The level of liquid nitrogen covered the level of the suspension. The suspension was checked constantly until complete freeze was observed. The universal was transferred to a water bath $\left(37^{\circ} \mathrm{C}\right)$ for thawing. To do this, the water bath was placed in the incubator in order to maintain the temperature constant. The suspension was checked constantly until complete thawing was observed. The extreme variation in temperature (from $-80^{\circ} \mathrm{C}$ to $37^{\circ} \mathrm{C}$ ) provoked a thermal shock causing the cells to rupture and adenoviral vectors to be released. In order to remove cell debris, the suspension was centrifuged at $2000 \mathrm{~g}$ for 10 min at $4^{\circ} \mathrm{C}$. The supernatant or crude virus lysate (CVL) was removed aseptically and aliquoted into labeled sterile containers and stored at $-80^{\circ} \mathrm{C}$. Crude cell lysate (CCL) was prepared following the same procedure as for CVL, but with uninfected cells.

\section{Plaque Assay}

The adenovirus infectivity was determined by the biological method plaque assay, via the inoculation of a statistically countable number of infective particles of an immobilized monolayer of cells. Each infective particle, when replicated, provoked a local cytopathic effect (CPE), initiated by rounding and clumping of the cells. Each zone affected by a $\mathrm{CPE}$ was visible and assuming that each CPE zone was caused by a single particle, the number of infective particles in the original sample could be estimated [21].

The 911 cells were seeded in 6 well plates at a density of $5 \times 10^{5}$ cells/well in $3 \mathrm{ml}$ of DMEM supplemented with 2 $\mathrm{mM}$ L-glutamine, $10 \% \mathrm{v} / \mathrm{v}$ hiFCS and $50 \mathrm{U} / \mathrm{ml}$ antibioticantimycotic. The plates were incubated at $37^{\circ} \mathrm{C}$ in a $5 \% \mathrm{CO}_{2}$ humidified atmosphere for 2 days until confluent monolayers formed. Adenoviral vectors samples were diluted with DMEM supplemented with $2 \mathrm{mM}$ L-glutamine and $2 \% \mathrm{v} / \mathrm{v}$ hiFCS with dilution factors ranging from $2 \times 10^{-3}$ to $2 \times 10^{-10}$. The growth medium of the well plates was replaced with 500 $\mu \mathrm{l} /$ well of the diluted adenoviral vector sample and each dilution was prepared in duplicate. The plates were infected for $90 \mathrm{~min}$ at $37^{\circ} \mathrm{C}$. At the end of the infection period of time, the medium was removed. The monolayers were overlaid with $3 \mathrm{ml} /$ well of Modified Eagle's Medium (MEM) supplemented with $1.85 \%$ hiFCS, $1.24 \% \mathrm{MgCl}_{2}$ and $50 \%$ noble agar (Sigma-Aldrich Ltd, UK). The overlay medium was kept at $42^{\circ} \mathrm{C}$ prior to utilization to inhibit gel formation. The plates were incubated at $37^{\circ} \mathrm{C}$ in a $5 \% \mathrm{CO}_{2}$ humidified atmosphere for 14 days. The cells were fed after 7 days by adding a further $2 \mathrm{ml} /$ well of overlay medium. On day 13 the cells were stained with $2 \mathrm{ml} /$ well of $0.02 \% \mathrm{v} / \mathrm{v}$ neutral red 
solution in order to enhance the visualization of the plaques. The plates were further incubated at $37^{\circ} \mathrm{C}$ in a $5 \% \mathrm{CO}_{2}$ humidified atmosphere for 3 hours before the staining solution was removed. On day 14 the plaques were counted from the duplicates where the number of plaques per well was typically in the range of 30 and 100 and the average number was recorded. The adenovirus titer in $\mathrm{pfu} / \mathrm{ml}$ was calculated by considering the dilution factor and the sample volume.

\section{Flow Cytometry}

The infectivity of adenoviral vectors was additionally determined by flow cytometry [22]. The attached 293 and A549 cells were grown in T-25 flasks to at least $80 \%$ of confluence. The cells were counted by hemocytometer and infected with $200 \mu \mathrm{l}$ of serial dilutions of the adenovirus stock prepared in infection medium (DMEM $+2 \%$ hiFCS). After 90 min of incubation at $37^{\circ} \mathrm{C}$ (gentle rocking with a periodicity of $20 \mathrm{~min}$ ), $3 \mathrm{ml}$ of infection medium was added to each flask (adenovirus containing medium was not removed). After 17 to $20 \mathrm{~h}$ of incubation the supernatant was collected in a universal sample tube and the cells were sedimented by centrifugation and washed with $2 \mathrm{ml}$ of sterile PBS. Cells were trypsinised and $2 \mathrm{ml}$ of infection medium was added before the cells were collected in the same container.

Aliquots of $500 \mu \mathrm{l}$ of each suspension were immediately analyzed in a Coulter EPICS Elite Analyzer equipped with an argon ion laser set at $488 \mathrm{~nm}$. The green fluorescence signal was collected by a photomultiplier tube after passing through a $525( \pm 20) \mathrm{nm}$ band pass filter (PMT2). The PMT2 amplifier was calibrated every day with standard fluorospheres Flow-Check ${ }^{\mathrm{TM}}$ (Beckman Coulter). Single viable cells were gated on the basis of the side-angle light scatter (PMT1 LOG) and the forward-angle light scatter (FS). The green fluorescent protein (GFP) fluorescence of $3 \times 10^{4}$ single viable cells per sample selected on FS versus SS scatter basis, was analyzed and high fluorescent cells were gated.

The cytometric parameters were set to provide accurate discrimination between non-fluorescent (or self-fluorescent) negative cells and positive GFP-fluorescent cells on a PMT2 LOG (gain 1, voltage ranging from 400 to $600 \mathrm{~V}$ depending on the signal) versus FS density plot in order to estimate the proportion of infected cells. Listmode data analyses were performed using software packages for accurate exploitation. The results were expressed as green fluorescent units per milliliter (gfu/ml).

\section{RESULTS}

\section{Production of Adenoviral Vectors in Attached 293 Cells}

In the present study a MOI of 10 and a MOI of 50 were selected to infect the 293 cells to ensure the infection event. As indicated in Fig. (1) for a MOI of 10 the cell density decreased dramatically after $48 \mathrm{hpi}$. The highest adenoviral vector titer obtained at $48 \mathrm{hpi}$. Both titration methods resulted in similar profiles during the production of adenoviral vectors.

When attached 293 cells were infected at a MOI of 50 the maximum titer was obtained at 48 hpi (Fig. 2) as obtained at a MOI of 10 . However, the titer did not decrease dramatically at $48 \mathrm{hpi}$. The maximum titer obtained at a MOI of 50 was nearly five times higher than that obtained at a MOI of 10 .

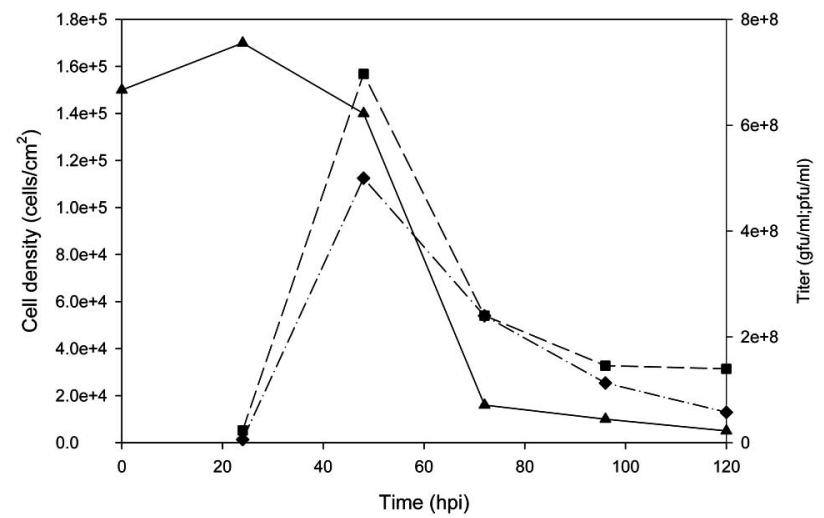

Fig. (1). Adenoviral vector production in attached 293 cells grown in SCM and infected at a MOI of 10. Every $24 \mathrm{~h}$ one flask was analyzed for cell density and infectivity by flow cytometry and plaque assay. ( $\mathbf{\Delta})$ Cell density $\left(\right.$ cells $\left./ \mathrm{cm}^{2}\right) ;(\boldsymbol{\square})$ Titer obtained by flow cytometry $(\mathrm{gfu} / \mathrm{ml})$ and $(\diamond)$ Titer obtained by plaque assay (pfu/ml).

According to the results obtained where the highest titer at different values of MOI studied was $48 \mathrm{hpi}$, the harvest time for the attached 293 cells was determined. This time was important because at this point the maximum viable infected cells could be harvested and therefore the maximum adenoviral vectors titer could be obtained.

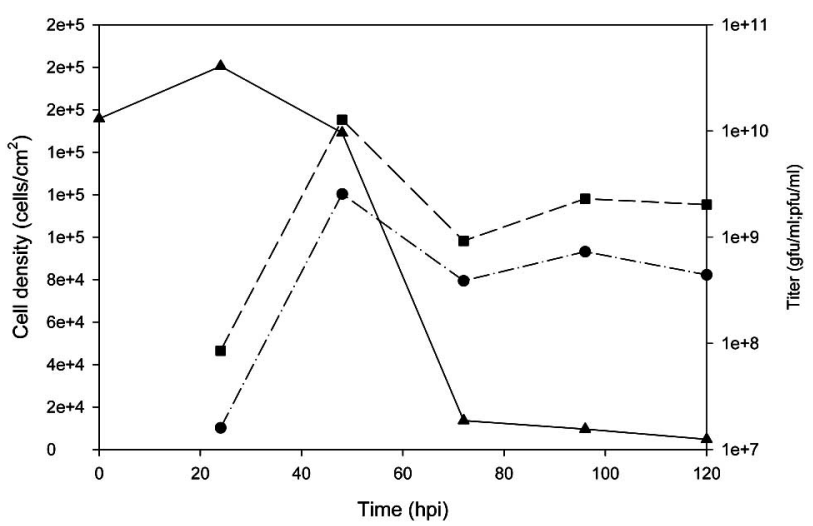

Fig. (2). Adenoviral vector production in attached 293 cells grown in SCM and infected at a MOI of 50. Every $24 \mathrm{~h}$ one flask was analyzed for cell density and infectivity by flow cytometry and plaque assay. ( $\mathbf{\Delta}$ ) Cell density (cells/cm2); ( $\mathbf{\square})$ Titer obtained by flow cytometry $(\mathrm{gfu} / \mathrm{ml})$ and $(\diamond)$ Titer obtained by plaque assay (pfu/ml).

\section{Production of Adenoviral Vectors in 293 Cells Grown in Suspension}

In order to compare the production of adenoviral vectors, 293 cells were grown in attached and suspension cultures. The attached 293 cells were adapted to grow in suspension by subculturing three times at $3 \times 10^{5}$ cells $/ \mathrm{ml}$ in different medium ratios of SCM and SFM in order to gradually adapt 
the cells to SFM. The percentages of SCM included $85 \%$, $70 \%, 50 \%, 30 \%, 15 \%$ and $0 \%(\mathrm{v} / \mathrm{v})$. In order to complete the total volume $(10 \mathrm{ml}), 293 \mathrm{SFM}$ II was added. At the end of the process the 293 cells were adapted to grow in suspension without the formation of aggregates in 293 SFM II.

The data in Fig. (3) shows that at a MOI of 10 the cell density decreased gradually during the process. This behavior was different to that observed in attached cells infected at the same MOI.

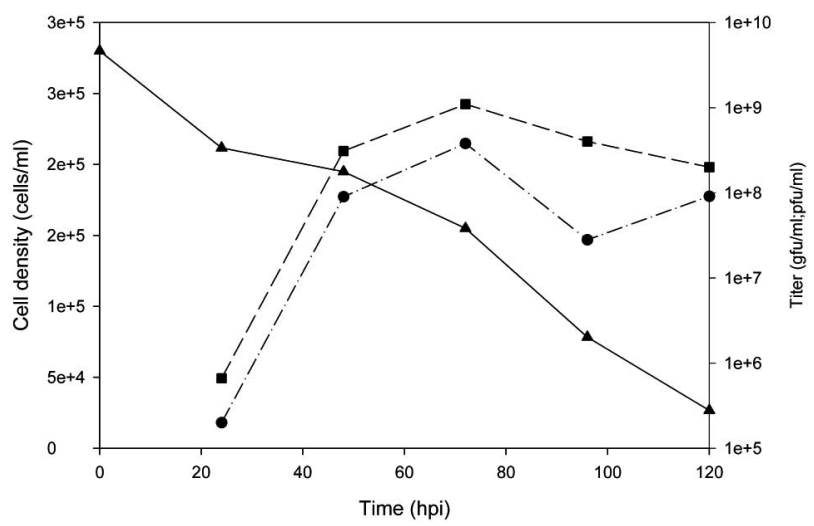

Fig. (3). Adenoviral vector production in suspension adapted 293 cells growing in SFM and infected at a MOI of 10. Samples were analyzed every $24 \mathrm{~h}$ for cell density and infectivity by flow cytome-

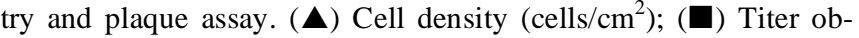
tained by flow cytometry $(\mathrm{gfu} / \mathrm{ml})$ and $(\diamond)$ Titer obtained by plaque assay $(\mathrm{pfu} / \mathrm{ml})$.

Fig. (4) illustrates the adenoviral vector production in suspension adapted 293 cells infected at a MOI of 50, where the cell density decreased dramatically after $24 \mathrm{hpi}$.

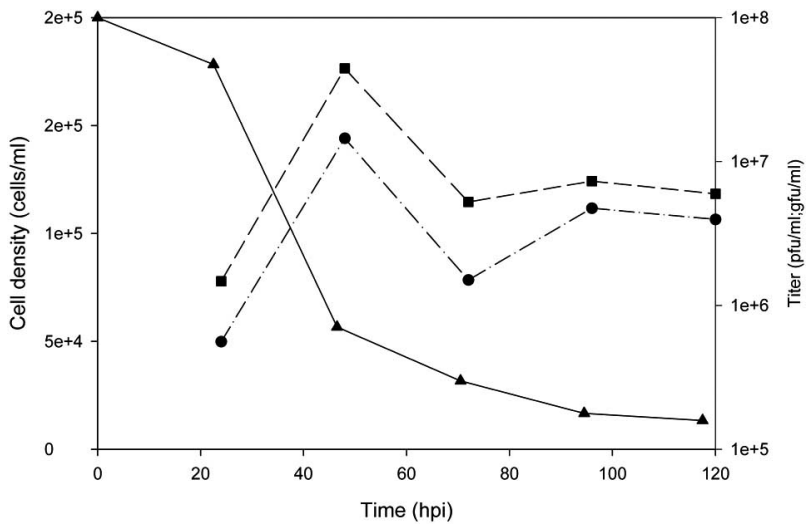

Fig. (4). Adenoviral vector production in suspension adapted 293 cells growing in SFM and infected at a MOI of 50. Every $24 \mathrm{~h}$ samples were analyzed for cell density and infectivity by flow cytome-

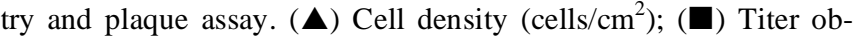
tained by flow cytometry $(\mathrm{gfu} / \mathrm{ml})$ and $(\diamond)$ Titer obtained by plaque assay $(\mathrm{pfu} / \mathrm{ml})$.

\section{Effect of Agitation Upon 293 Cells}

The suspension adapted 293 cells were grown in 293 SMF II medium into two $250 \mathrm{ml}$ sterile spinner flasks with
$120 \mathrm{ml}$ working volume. The initial cell density in both flasks was $1.5 \times 10^{5}$ cells $/ \mathrm{ml}$ with $90 \%$ viability. One flask was stirred magnetically at $80 \mathrm{rpm}$. This agitation speed was lower than that reported previously for a similar cell line, ranging from $100 \mathrm{rpm}$ to $140 \mathrm{rpm}[12,15]$. Both cultures were incubated at $37^{\circ} \mathrm{C}$ in a $5 \% \mathrm{CO}_{2}$ atmosphere. Samples were taken every 24 hours for cell density and cell viability determination. The $\mathrm{pH}$ was also monitored.

As indicated in Fig. (5) the cell density of the suspension adapted 293 cells was strongly influenced by agitation. The cell density decreased considerably from the beginning of the process in the agitated culture. After $120 \mathrm{~h}$ of incubation the agitated culture was not monitored because there were no remaining viable cells. The cell density of the non-agitated spinner flask started decreasing after $72 \mathrm{~h}$ of incubation.

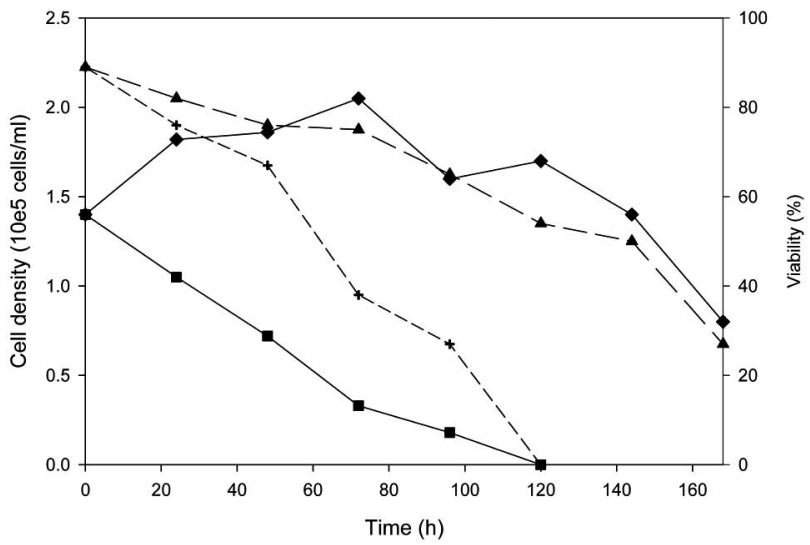

Fig. (5). Effect of agitation upon cell density and viability of suspension adapted 293 cells growing in SFM. Samples taken every 24 $\mathrm{h}$ were analyzed. Control: $(\bullet)$ cell density without agitation (cells $/ \mathrm{ml}$ ) and $(\boldsymbol{\Delta})$ cell viability without agitation $(\%)$. Agitated culture: $(\boldsymbol{\square})$ cell density (cells/ml) and $(\times)$ cell viability $(\%)$.

It can be noted from Fig. (5) that the viability of the agitated 293 cells decreased dramatically after $48 \mathrm{~h}$ of incubation in comparison with the cells without agitation where the viability decreased gradually. At $120 \mathrm{~h}$ of incubation the viability of the cells in the agitated spinner flask reached zero.

The $\mathrm{pH}$ was monitored in order to evaluate the buffer properties of the 293 SFM II media during the culture of 293 cells. Fig. (6) illustrates a gradual decrease in the $\mathrm{pH}$ of the non-agitated culture. Conversely, in the case of the agitated culture the $\mathrm{pH}$ remained stable during the process.

\section{DISCUSSION}

The cell infection is a diffusion-limited process where only a fraction of infective particles present in the medium diffuse to the monolayer within the time of infection [23]. A successful infection of a cell by an adenovirus depends firstly on the collision of a virus with a cell. In attached cells this only occurs by adenovirus motion, while in suspension culture conditions this is mostly limited to Brownian motion resulting in insignificant net movement [24]. At a MOI of 5 most of the attached 293 cells are infected by at least one infective adenoviral vector [22]. The probability that the 
adenoviral vectors collide with cells during suspension culture is much lower than in attached culture.

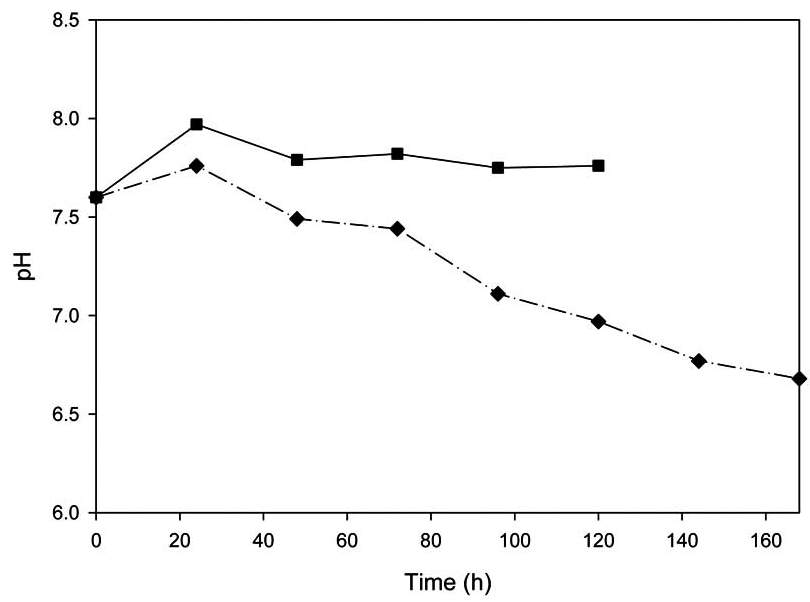

Fig. (6). pH variation in suspension adapted 293 cell culture. The suspension adapted 293 cells were grown in $250 \mathrm{ml}$ spinner flasks in SFM. The 293 SFM II buffer property was evaluated in agitated (80 rpm) and non-agitated systems by $\mathrm{pH}$ measurement every $24 \mathrm{~h}$ without medium replacement during the process. $(\bullet) \mathrm{pH}$ variation in the culture without agitation; ( $\mathbf{\square}) \mathrm{pH}$ variation in the culture agitated at $80 \mathrm{rpm}$.

In Fig. (1) the dramatically decrease in cell density after 48 hpi may be due to the fact that most cells had released the adenoviral vectors to the medium and the titration methods used only quantify those that remain intracellular. Many cells burst releasing the adenoviral vectors (Fig. 7), accompanied by some intracellular compounds such as proteolytic enzymes, which affect the neighboring cells of the monolayer. This, in combination with the accumulation of products from the cellular metabolism in the medium, may cause the decrease in cell density. The highest adenoviral vector titer obtained at $48 \mathrm{hp}$ correlated with that obtained in previous studies [22]. Both titration methods resulted in similar profiles during the production of adenoviral vectors. This agreed with the correlation between plaque assay and flow cytometry reported previously [22].

At a MOI of 10 , the titer did not decreased dramatically after 48 hpi may be due to the fact that the excess of adenoviral vectors present in the original inoculum was only attached to the cell surface and thus those particles were inevitably included in the titration by the methods used.

Comparing the titers obtained at a MOI of 50 (Fig. 2) and a MOI of 10 (Fig. 1), the highest titer was obtained with an MOI of 50, where more adenoviral vectors per cell multiple infections can occur until a saturation point [15, 22, 24]. In this case, the adenoviral vectors were present in sufficient amounts considering the different values of MOI reported previously for this cell line [22]. The pattern of results for cell density obtained at a MOI of 50 correlated with that observed at a MOI of 10 .

From two different values of MOI, the highest titer obtained at 48 hpi become very important because, it can be concluded that a MOI of 10 was appropriate for adenoviral vectors production under the conditions established. The lowest MOI value achieving the highest production of adenoviral vectors avoids unnecessary use of adenoviral vectors, resulting in savings in bio-material and hence finances. In order to determine the possibility of producing adenoviral vectors in 293 cells adapted to grow in suspension, the same values of MOI were investigated.

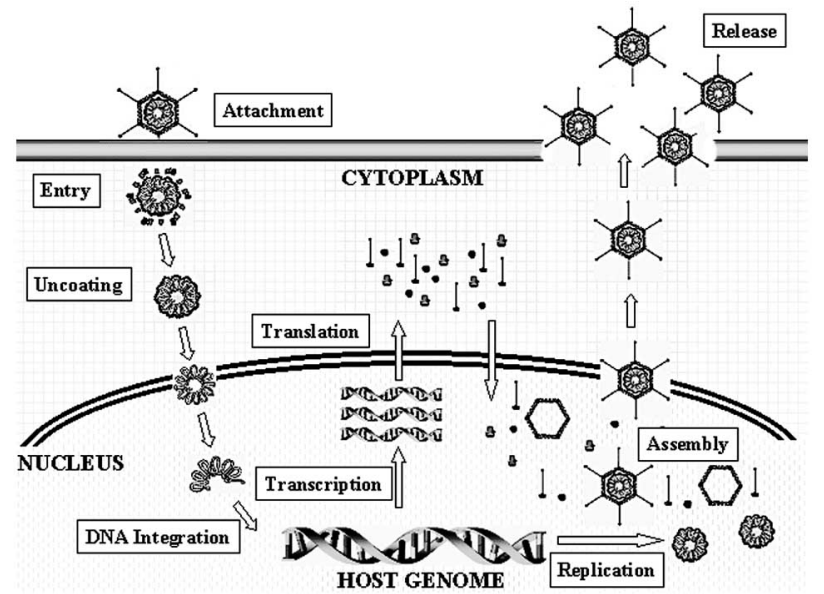

Fig. (7). Replicative cycle of adenovirus. The adenovirus attaches by the fibers to the cell membrane receptors and enters the cell by endocytosis. The uncoating process takes place in the cytoplasm. The DNA migrates through a net of microtubules to the nucleus where it is released. The DNA integrates to the host genome and transcription and replication occur. The mRNAs of the protein components of the adenovirus are translated in the cytoplasm. The protein components of the adenovirus are concentrated in the nucleus where the assembly with the adenovirus DNA takes place. After the maturation process the adenoviruses produced are released from the nucleus and from the cell by bursting the cell membrane. The released infective adenoviruses can now infect other cells.

The difference in cell density pattern observed in cells growing in suspension and infected at a MOI of 10 (Fig. 3) compared to that at a MOI of 50 could be attributed to the fact that although many intracellular compounds were released in conjunction with the adenoviral vector release, the cells were not as close to each other as they were when growing in monolayer. This behavior was supported by the gradual decrease in titer profile after the maximum value was reached. This suggested that the remaining living cells were still producing adenoviral vectors. In this case, the highest adenoviral vector titer was obtained at $72 \mathrm{hpi}$, which is $24 \mathrm{~h}$ later than in the attached cell experiments. This may be due to the fact that it takes more time for the collisions to occur between the adenoviral vectors and the cells in suspension at the value of MOI used. Similar to attached cells, the titer of adenoviral vectors obtained from cells in suspension by both titration methods agrees with the comparisons reported previously [22].

The dramatically decrease in cell density after 24 hpi (Fig. 4) differed from that observed at MOI 10 for the same cell line but it was similar to that obtained in attached cells at the same MOI. This may be due to the fact that infected suspended cells are more fragile than the non-infected cells especially when they are growing in SFM. This correlated with the results reported previously for the 293 cells growing in a different SFM [9]. Similarly to attached cells, the highest 
adenoviral vector titer was obtained at 48 hpi. This result differed from that obtained in suspension cells at a MOI of 10. Furthermore, it had to be considered that at MOI of 50 there were five times more adenoviral vectors than there were at a MOI of 10 . This increased the probability of collisions between the adenoviral vectors and the cells and hence the number of infected cells increased. From 72 hpi until the end of the process the considerably high titers determined by both titration methods remained steady. This suggested that the remaining live cells continued to produce infective adenoviral vectors. According to this result the best harvesting time was $48 \mathrm{hpi}$ for the conditions established. It is interesting to note in the titer profiles of both values of MOI studied, that the maximum titer obtained at a MOI of 10 was higher than that at a MOI of 50. It has to be considered however, that the former titer was obtained at $72 \mathrm{hpi}$ and at a MOI of 50 after $48 \mathrm{hpi}$. This would represent a large difference in terms of production time and hence in cost at larger-scale production. This showed that the harvesting time is a parameter that has to be determined accurately, especially for the optimization of large-scale processes.

During the culture of microbial cells, oxygen transfer rates can be improved by decreasing bubble size, using higher stirring speeds and a higher gas hold-up. However, such adjustments are not practical in mammalian cell cultures [25]. This is due to the fragile nature of animal cells, which can be damaged under conditions of high turbulence $[26,27]$. Hence, in mammalian cell culture the objectives of maximizing oxygen transfer rates must be balanced with the maintenance of the integrity of the cell membrane [28, 29].

Agitation and aeration are critical parameters in the larger-scale cultivation of mammalian cells in order to achieve the appropriate mass and heat transfer. These cells are shear sensitive due to the protection from the environment by the cell membrane only. The major physical forces during cell culture that can cause cell damage include shear forces and bubble energy [28, 30, 31].

The considerable decrease in cell density in agitated culture (Fig. 5) could be attributed to the agitation effect upon the cells because the cell density in the culture without agitation increased during the first $72 \mathrm{~h}$ of incubation as expected. However, in the non-agitated culture cell density decreased after 72 hpi. This effect may be due to the normal consumption of nutrients and accumulation of metabolites in the medium since the medium was not replaced during the process. Additionally, in the non agitated culture the cells were settled forming layers. This could limit the mass transfer and provoke oxygen limitation due to low availability of $\mathrm{O}_{2}$. This result showed that the subculture time for maintaining the suspension adapted 293 cells was $24 \mathrm{~h}$ longer than that for attached cells. At $72 \mathrm{~h}$ the suspended cells were still in exponential phase with viability around $80 \%$ (Fig. 5). At this point the cell density could be adjusted and the culture medium was replaced by fresh medium. This allowed for the subculture of such cells three times per week, reducing the consumption of medium and material necessary to maintain the culture. The minimum cell density reached at $120 \mathrm{hpi}$ of the agitated culture (Fig. 5) was attributed to the agitation effect upon the cells since the cells without agitation presented viability around $30 \%$ even at $168 \mathrm{~h}$ of incubation. This may be due to the inappropriate adaptation of the cells to grow in suspension since the cells did not duplicate during the first $72 \mathrm{~h}$ of culture. According to the results obtained, the agitation played an important role during the culture of suspension adapted 293 cells having a negative effect upon cell density and viability. The addition of a surfactant could help to overcome this problem, which has been reported previously for different mammalian cells [31-35].

The gradual decrease in $\mathrm{pH}$ of the non-agitated culture (Fig. 6) was attributed to the accumulation of acidic metabolites such as lactate in the medium $[10,12]$, which is quantitatively the major metabolic bioproduct of the 293 cells, accumulating to a maximum of $50 \mathrm{mM}$ in $72 \mathrm{~h}$ of culture [12]. The minimum lactate concentration that inhibits the growth of mammalian cell lines varies between 10 and $70 \mathrm{mM}$ [36]. This result showed the low buffer capacity of the 293 SFM II. On the other hand, the stable $\mathrm{pH}$ determined in the agitated culture was explained by the negligible accumulation of such metabolites by the low cell density present in the system (Fig. 5). According to the results obtained, it was necessary to add a buffer to the 293 SFM II in order to avoid any significant change in $\mathrm{pH}$.

\section{CONCLUSIONS}

In the present study, it was demonstrated that the 293 cells can be adapted to grow in suspension using serum free medium for the production of adenoviral vectors. The use of a consistent formulation of SFM commercial available facilitates the reproducibility among productions. Titers ranging from $10^{8}$ to $10^{9} \mathrm{pfu} / \mathrm{ml}$ were obtained when suspension adapted cells were infected at a MOI of 10 . It was determined effect of different parameters including agitation and $\mathrm{pH}$ upon cell culture during the process. The production technique using suspension culture demonstrated here is expected to facilitate scale up and enabling accurate monitoring and control of culture. This also provides valuable information for the process development for the production of adenoviral vectors for gene therapy applications.

\section{ACKNOWLEDGEMENTS}

The authors gratefully acknowledge the financial support from the National Council of Science and TechnologyMexico (CONACYT).

\section{REFERENCES}

[1] Ferreira TB, Alves PM, Aunins JG, et al. Use of adenoviral vectors as veterinary vaccines. Gene Ther 2005; 12: S73-83.

[2] Zhang C, Ferreira TB, Cruz PE, et al. The importance of 293 cell cycle phase on adenovirus vector production. Enzyme Microb Technol 2006; 39: 1328-1332.

[3] Iyer P, Ostrove M, Vacante D. Comparison of manufacturing techniques for adenovirus production. Cytotechnology 1999; 30: 169172.

[4] Chu L, Robinson DK. Industrial choices for protein production by large-scale cell culture. Curr Opin Biotechnol 2001; 12: 180-187.

[5] Kamen A, Henry O. Development and optimization of an adenovirus production process. J Gene Med 2004; 6: S184-S192.

[6] Lydersen BK, Ed. Large scale cell culture technology. Hanser: Wemding; 1987.

[7] Graham FL. Growth of 293 cells in suspension culture. J Gen Virol 1987; 68: 937-940.

[8] Molina-Grima E, Chisti Y, Moo-Young M. Characterization of shear rates in airlift bioreactors for animal cell culture. J Biotechnol 1997; 54: 195-210. 
[9] Côté J, Garnier A, Massie B, et al. Serum-free production of recombinant proteins and adenoviral vectors by 293SF-3F6 cells. Biotechnol Bioeng 1998; 59: 567-575.

[10] Epstein DA, Godwin GP, Gruber DF, et al. Serum-free suspension culture of 293 cells. Focus 1999; 21: 22-24

[11] Graham FL, Smiley J, Russell WC, et al. Characterization of a human cell line transformed by DNA from adenovirus 5. J Gen Virol 1977; 36: 59-72

[12] Garnier A, Côté J, Nadeau I, et al. Scale-up of the adenovirus expression system for the production of recombinant protein in human 293S cells. Cytotechnology 1994; 15: 145-155.

[13] Nadeau I, Garnier A, Côté J, et al. Improvement of recombinant protein production with the human adenovirus/293S expression system using fed-batch strategies. Biotechnol Bioeng 1996; 51: 613-623

[14] Shabram PW, Giroux DD, Goudreau AM, et al. Analytical anionexchange HPLC of recombinant type-5 adenoviral particles. Hum Gene Ther 1997; 8: 453-465.

[15] Schoofs G, Monica TJ, Ayala J, et al. A high-yielding serum-free, suspension cell culture process to manufacture recombinant adenoviral vectors for gene therapy. Cytotechnology 1998; 28: 81-89.

[16] Côté J, Bourget L, Garnier A, et al. Study of adenovirus production in serum-free 293SF suspension culture by GFP-expression monitoring. Biotechnol Progress 1997; 13: 709-714.

[17] Jani A, Lochmüller H, Acsadi G, et al. Generation, validation, and large scale production of adenoviral recombinants with large size inserts such as a $6.3 \mathrm{~kb}$ human distrophin cDNA. J Virol 1997; 64: 111-124.

[18] Monica TJ, Montgomery T, Ayala JL, et al. Monitoring adenovirus infections with on-line and off-line methods. Biotechnol Progr 2000; 16: 866-871.

[19] Nadeau I, Gilbert PA, Jacob D, et al. Low-protein medium affects the 293SF central metabolism during growth and infection with adenovirus. Biotechnol Bioeng 2002; 77: 91-104

[20] Fallaux FJ, Kranenburg O, Cramer SJ, et al. Characterization of 911: A new helper cell line for the titration and propagation of early region 1-deleted adenoviral vectors. Hum Gene Ther 1996; 7: 215-222.

[21] Cooper PD. The plaque assay of animal viruses. Adv Virus Res 1961; 8: 319-378

[22] Gueret V, Negrete-Virgen JA, Lyddiatt A, et al. Rapid titration of adenoviral infectivity by flow cytometry in batch culture of infected HEK293 cells. Cytotechnology 2002; 38: 87-97.
[23] Mittereder N, March KL, Trapnell BC. Evaluation of the concentration and bioactivity of adenovirus vectors for gene therapy. $\mathrm{J} \mathrm{Vi}$ rol 1996; 70: 7498-7509.

[24] Nyberg-Hoffman C, Shabram P, Li W, et al. Sensitivity and reproducibility in adenoviral infectious titer determination. Nat Med 1997; 3: 808-811

[25] Emery AN, Jan DC, Al Rubeai M. Oxygenation of intensive cellculture system. Appl Microbiol Biotechnol 1995; 43: 1028-1033.

[26] Al Rubeai M, Emery AN, Chalder S, et al. A flow cytometric study of hydrodynamic damage to mammalian cells. J Biotechnol 1993; 31: 161-177.

[27] Thomas CR, Al Rubeai M, Zhang Z. Prediction of mechanical damage to animal cells in turbulence. Cytotechnology 1994; 15 329-335

[28] Kunas KT, Papoutsakis ET. Damage mechanisms of suspended animal cells in agitated bioreactors with and without bubble entrainment. Biotechnol Bioeng 1990; 36: 476-483.

[29] Langheinrich C, Nienow AW, Eddleston T, et al. Oxygen transfer in stirred bioreactors under animal cell culture conditions. Biotechnol Bioeng 2002; 80: 39-44.

[30] Oh SKW, Nienow AW, Al Rubeai M, et al. Further studies of the culture of mouse hybridomas in an agitated bioreactor with and without continuous sparging. J Biotechnol 1992; 22: 245-270.

[31] Nienow AW. Large scale free suspension animal cell culture: cell fragility versus media homogeneity. Genet Eng Biotechnol 1997; 17: 111-113.

[32] Zhang S, Handa-Corrigan A, Spier RE. Foaming and media surfactant effects on the cultivation of animal cells in stirred and sparged bioreactors. J Biotechnol 1992; 25: 289-306.

[33] Al Rubeai M, Emery AN, Chalder S. The effect of Pluronic F-68 on hybridoma cells in continuous culture. Appl Microbiol Biotechnol 1992; 37: 44-45.

[34] Chattopadhyay D, Rathman JF, Chalmers JJ. The protective effect of specific medium additives with respect to bubble rupture. Biotechnol Bioeng 1995; 45: 473-480.

[35] Kioukia N, Nienow AW, Emery AN, et al. Physiological and environmental factors affecting the growth of insect cells and infection with baculovirus. J Biotechnol 1995; 38: 243-251.

[36] Glacken MW. Catabolic control of mammalian cell culture. Biotechnology 1988; 6: 1041-1050. 